\title{
Self-knowledge as a criterion for classifying philosophical doctrines
}

\author{
Leysan R. Slobozhankina - Marina S. Teplykh - Marina P. Akhmetzyanova \\ - Vera A. Zhilina - Alevtina I. Nazaricheva
}

DOI: 10.18355/XL.2018.11.02.35

\begin{abstract}
One of the important issues while teaching the course "Philosophy" is the classification of philosophical doctrines. That is because philosophy as a single, universally recognized system of knowledge does not exist. There are a lot of different philosophical doctrines, schools, currents, trends, which in some ways are unite with each other, but more in contradiction, struggle, and refute each other. The article concentrates on revealing the philosophy, in its real historical existence, as a set of "philosophies". The purpose of this article is to disclose the possibility of applying a convenient and understandable method for classifying philosophical schools and trends, for successfully mastering the history of philosophy. To make a student understand this diversity of "philosophies" better, the method of classification is applied. The materials of the article are of practical value for specialists engaged in philosophical educational programs in learning environment.
\end{abstract}

Key words: Self-knowledge, philosophical truth, classification, philosophical teachings, history of philosophy

\section{Introduction}

The aim of the research is to fill the gap in the study of classifications of philosophical doctrines. There are many of them at present, but no one among the researchers has not established self-knowledge as the main criterion in classifying philosophical teachings. A more familiar form of the question is discussed, "What is primary: selfknowledge or cognition?" ("What is primary in philosophy: the subject of selfknowledge (how can I change to reveal the truth?") or the subject of knowledge is being researched (how can I know the truth?)).

To achieve this aim, the authors have accomplished the following tasks:

1. To make an analysis of the concepts and ideas available on this topic in the domestic and foreign historical and philosophical literature, clarifying the thematic limits of research and the available research approaches on the topic.

2. To give a further definition of the concept: "self-knowledge"; revealing its constituent elements and characteristics.

3. To outline the circle of the given problems, such as the classification of doctrines adopted in the history of philosophy, the problem of the unity of faith and reason, the problem of the genesis of knowledge (higher contemplative and experienced knowledge), the problem of knowledge transfer.

4. To consider the criterion of self-knowledge and the directions selected on its basis.

5. To identify the practical significance of this classification.

The hypothesis of this article is that this classification will help philosophical currents to make a breakthrough from pure theory into the practical sphere of philosophizing, to study the so-called applied philosophical thought more carefully.

\section{Methodological Framework}

When a new method for classifying philosophical doctrines is revealed, a dialectical and axiological approach to research is applied. The axiological approach as the methodology of this research is characterized by its specific focus on the development of value orientations of any person studying the basic problems of philosophy. In the

XLinguae, Volume 11, Issue 2, April 2018, ISSN 1337-8384, eISSN 2453-711X 
process of classification, universally valid principles are singled out that determine the direction of human activity, the motivation of human actions. The concept of "value" is different in the way that it does not function autonomously. A lot of different theories have been created about the phenomenon of "value". Therefore, this phenomenon is considered from the point of view of theoretical knowledge and moral practical action. Philosophers consider the doctrine of meaningful values, regard values as content, moral standards, which form a system in the moral formation of the personality. Applying a dialectical approach to research in identifying a new classification, we were guided by the following principles: the development of historical phenomena that constantly function, develop, adapt to constantly changing conditions; continuity, the newly emerging phenomena reproduce the features of already existing phenomena; contradictions: the struggle of the opposite sides of the object is the most important component of the development process; scientific: in order to achieve the most effective research it is necessary to be able to foresee the phenomena, this can be achieved by using everything new and progressive.

\section{Results and Discussions}

On the basis of the criterion of self-knowledge, the types of philosophizing that we have identified allow us to designate in a schematic way the history of philosophy as a consistent succession of them.

Indeed, philosophy, originated in antiquity as a practical philosophizing aimed at selfcognition of a person in the process of its spiritual and practical perfection. The West European historical movement has replaced it by theoretical philosophizing aimed at cognition of reality external to human subjectivity.

On the one hand, the marked path of the historical movement of philosophy can be assessed as development and progress or as an upward movement from human subjectivity to intersubjectivity, from individualism to the collectivism of philosophical thinking.

On the other hand, this historical scheme can also be interpreted as a regression of philosophy losing its original, authentic meaning, the alienation of philosophy from human subjectivity, from the life, practical problems of a particular person. In this case, we think of the return of philosophy to its origins, or, speaking in dialectic, "returning to the supposedly old", but in a new form of understanding what philosophy is, what is its meaning and purpose.

As a criterion of philosophical doctrines, there is one or another question, to which thinkers give different answers-teachings. The most famous criterion is the so-called "fundamental question of philosophy" according to Friedrich Engels - the question of the relation of thinking to being (or, in other words, the spirit to matter). "The great and fundamental question of the whole, especially of the newest philosophy," wrote Engels, "is the question of the relation of thinking to being" (Marx \& Engels, 1961). In the ontological version of this question ("What is primary: material or ideal?"), philosophers are divided into materialists and idealists, in the epistemological version ("Do we know the world?") we distinguish epistemological optimism, skepticism and agnosticism in philosophy.

Other classification criteria are also applied. In philosophy there are monism, dualism and pluralism, that answer the question how many sources at the basis of existence are. There are theism and atheism, that discuss if a God's exists. Metaphysics and dialectics think over the problem of the development. Determinism and indeterminism work on the question "Is there freedom in the existent?"), Rationalism and irrationalism try to answer the question: "Is it reasonable to arrange things?" There are also many other teachings.

The choice of one criterion or another for the classification of philosophical doctrines, or more precisely, the separation of "basic" and "secondary" criteria-classification 
questions, has not only the teaching and methodological meaning but also historical and philosophical as well as meta-philosophical significance.

In the historical-philosophical context, the choice of the main criterion of classification explains the fact that the history of philosophy used to be a struggle, a dispute of thinkers around this issue. This idea is fixed in different schemes of philosophical knowledge development ("How did philosophy develop?"). Thus, according to the traditional understanding of the "basic question", the history of philosophy is represented as a struggle of two directions - the "Democritus line" (materialism) and the "Platonic line" (idealism).

In the meta-philosophical (or conceptual) context, the choice of the main criterion of classification appears as the basis of the philosophy itself, its interpretation. It predetermines the subject, the main problems of philosophical reflection, the meaning, and purpose of philosophy, and leads to the reflexive position of seeking an answer to the question "What is philosophy?".

It should be noted that the historical-philosophical and meta-philosophical contexts are closely interrelated. Indeed, in order to answer the question "how did something exist in time (in this case, philosophy)?" It is necessary to have an idea of this "something". We must be sure that when considering the history of the existence of this "something", it did not turn into another "something" or did not cease to exist, turning into "nothing". Vice versa, having an idea of this "something", the researcher chooses a historical material describing the history of the existence of this "something".

G.V. Hegel (1993) pointed to the close relationship between philosophy and the history of philosophy, saying that the study of the history of philosophy "does not only depict only external and occurred events that make up the content, but shows how the historical content itself enters the science of philosophy. The history of philosophy itself is scientific and, let us say, even more, becomes the main science of philosophy" (Hegel, 1993).

Let us now turn to the criterion for classifying philosophical doctrines. From our point of view, they are avoided by both historians of philosophy in their studies and teachers of philosophy in educational and methodological literature.

This is the question of self-knowledge? That was formulated by Socrates at the origins of philosophy itself: "Man, know himself" (Cognosce te ipsum), it is the philosophical concept of "caring for oneself" (Epimeleia / cura sui). In ancient philosophy, as M. Foucault (2007) points out, the call to self-knowledge ("know oneself") was always accompanied by the demand to "take care of oneself": "This kind of philosophical thinking is reflected in the teaching of Socrates, who talks to people on the streets, asks the youth one question: do you care about yourself?".

Without going into details here, we formulate self-knowledge as the main criterion for classifying philosophical doctrines in the more familiar form of the question: "What is primary: self-knowledge or cognition?" In its expanded form it sounds like that: "What is primary in philosophy: the subject of self-knowledge (How can I change to reveal the truth?) or the subject of knowledge (How can I know the truth?) ".

In our opinion, according to this criterion, it is possible to divide philosophical doctrines, with a certain degree of conventionality, in the following directions of philosophizing (types of philosophical thinking):

- Practical philosophizing (practical philosophical thinking);

- Theoretical philosophizing (theoretical philosophical thinking);

Applied philosophizing (applied philosophical thinking).

Let us study the criterion of self-knowledge and the directions selected on its basis in detail.

First of all, we point out that the meaning of philosophy as a "love of wisdom" lies in the search for truth, as pointed out by Pythagoras, who introduced the term

XLinguae, Volume 11, Issue 2, April 2018, ISSN 1337-8384, eISSN 2453-711X 
"philosopher" to refer to people who "come to life ... hungry for the truth only" (Laertius, 2009). The search for truth is a question of ways (methods) of comprehending truth. Consequently, the differences between philosophical doctrines should be sought not only and not so much in different notions of truth (what is truth) as in the various ways of moving towards truth (how to achieve truth).

This means that we are interested not in the views of philosophers about being and / or their evaluation from the standpoint of the criteria of truth (for example, what is primary in being - spirit or matter, or who is closer to the truth - materialists or idealists), but philosophers' various ways of achieving the truth, ways of philosophizing. There are three methods of that - the practical method, the theoretical one and the applied one.

Practical philosophizing. Practical philosophizing should be understood as a type of philosophical thinking, which is based on the concept of philosophy as the comprehension of truth through the spiritual and practical transformation of the subject (the realization of practical experience) in the process of his individual selfdiscovery with the goal of discovering the truth in himself.

Practical philosophical thinking is based on the following statements:

- Philosophy is a spiritual search (practical activity, experience), through which the subject learns himself, realizing the transformations in himself, that are necessary to comprehend the truth. Philosophy is the switching of the view from the external (surrounding world, others) to the inner, to oneself, to what is happening within the spiritual world of the person himself.

- The main question of philosophy is not the question of "What is the truth?", but the question "What is the price of comprehending the truth?". This price is concluded in the subject itself in the form of a question: "What kind of work should I do myself? How should I transform myself? What changes do I have to make in order to understand the truth?"

- Truth is not known (achieved) by a person, but is revealed to him (is discovered by him) when he is ready for it. The subject can only comprehend the truth individually, taking the path of "taking care of oneself." That is, provided that he will carry out a series of operations, transformations, and modifications with himself that will make him capable, ready to perceive the truth.

- To achieve the truth, spiritual practices (exercises, techniques, skills) are necessary, realizing that a person changes and transforms himself.

- The personal experience of communicating with the Tutor (Teacher) plays a significant role in finding the way of understanding the truth.

Practical philosophical thinking originated and was realized in the teachings of antiquity. In ancient Indian philosophy the practical method includes the Vedic teaching of the Upanishads about the "expansion" of the human consciousness (Atman) to the state of the divine Absolute (Brahman) and Buddhist doctrine of the "eightfold path of enlightenment," the achievements of nirvana. In ancient Chinese philosophy this teaching includes the Taoist practices of non-deeds (wu-wei) on the way to comprehend the Tao and Confucian doctrine of the "noble husband" practicing the execution of the Will of Heaven (Hansen, 2010).

In the ancient tradition, practical philosophizing was formulated in the already mentioned Socratic-Platonic concept of "taking care of oneself" as a practical selfknowledge of the "divine self" and finding the truth in the "world of ideas". This includes the teachings of Cynics about happiness as individual freedom (eudemonism) that is achieved as a result of minimizing their needs; The doctrine of Democritus about the imperturbable joy of the spirit (euthume) and the teaching of Epicureans about the attainment of serenity of the spirit (ataraxia); The doctrine of skeptics about abstaining from judgments (epoch); The Stoic doctrine of indifference, the attainment of peace of mind as a result of changing one's attitude towards the happening. 
In medieval philosophy, there are numerous practical and religious teachings on ascetic asceticism, "intelligent work", mystical experience of spiritual prayer (hesychism) as ways of connecting a man with God.

In modern philosophy, there are also examples of practical philosophizing such as the doctrine of the call for the superman F. Nietzsche, the doctrine of existentialists about the creation by man of his essence in the "adventure" of self-development (J.P. Sartre, A. Camus, E. Fromm, etc.); the doctrine of "saving the subject" in the hermeneutics of M. Foucault (2007) and others (Ranganathan, 2018; Rodriguez, 2018).

Theoretical philosophizing. Theoretical philosophizing should be understood as the type of philosophical thinking that is based on the concept of philosophy as the comprehension of truth by developing the theory of true knowledge and the criteria of truth in the process of individual (collective, social and historical) knowledge with the aim of acquiring true knowledge in the forms of social consciousness (in science, in philosophy, in art, in religion, etc.).

Theoretical philosophizing is based on the following provisions:

- Philosophy is the comprehension of truth by creating such a theoretical system of knowledge that meets the criteria of true knowledge and allows the subject to know the object (the world, being) as it really is. Philosophy is aimed not at the knowledge of the subject, but at the knowledge of the object itself, at the reproduction of its essential characteristics (laws) in theoretical concepts.

- The main question of philosophy is the question "What is truth?" It is predetermined by the object of cognition itself (its laws are hidden from the subject). The problem of truth lies in the form of a question for the subject: "Which method should I use to uncover the truth? What criteria should I follow in order to evaluate the knowledge that is available as true? " (Kalashyan, 2011).

- Truth itself does not open to the subject. To achieve it, the subject must examine (experience) the object, learning (trying out) his secrets with the help of the correct methods of cognition. The subject of cognition "alone" is not able to build a system of true knowledge about the object. Truth is comprehended only by the collective subject of cognition, formed in the process of social and historical knowledge, the accumulation of knowledge.

- To achieve the truth, it is necessary for an individual subject to study (assimilate) those theoretical knowledge that has been accumulated by mankind in the process of historical development. A transition to the position of the collective subject of knowledge is necessary. Truth and the path of its attainment, therefore, can be alienated from a particular individual and objectified in the system of knowledge existing independently of a particular person.

- Mediated communication (mental dialogue) with the thinkers of the past and the present through critical examination of the theories (texts, works, books) created by them, plays an important role in the comprehension of the truth, thus revealing the shortcomings of existing knowledge and discovering new true knowledge. (Here the famous phrase of I. Newton is applicable: "If I saw further than others, then because I stood on the shoulders of giants").

A theoretical type of philosophizing arises in ancient philosophy, to a large extent determining the entire subsequent history of classical Western European philosophy. Its foundations were laid in the doctrine of the identity of being and thinking of the Eleatics, in the "negativist" reflections of the Sophists about the relativity of any truth, and, mainly, in Aristotle's doctrine of philosophy as a comprehension of truth by the method of rationalistic logic developed by him.

In the medieval tradition, theoretical philosophizing was realized when solving questions about the relationship between faith and reason in comprehending the truths of Scripture, in discussing the problem of the nature of universals. In the late Middle Ages, such theorizing led to an understanding of philosophy as scholasticism, based

XLinguae, Volume 11, Issue 2, April 2018, ISSN 1337-8384, eISSN 2453-711X 
solely on formal logical arguments for theoretical justification of the dogmas of the church.

In recent time, philosophers have mainly implemented theoretical philosophizing, studying philosophy as the methodology of scientific knowledge, called upon to find the true method of cognition (the dispute of empiricism with rationalism).

Perhaps the theoretical type of philosophizing has flourished in the works of the representatives of German classical philosophy, especially in the teaching of G.V. Hegel (1993), who saw philosophy as the highest form of theoretical knowledge of truth and the only science capable of comprehending the truth about the essence of the world and man. It was in G.V. Hegel's philosophy that the "ideal" of theoretical philosophizing became the embodiment of a theory in which the teachings of the preceding philosophers were represented by G.V. Hegel (1993) as part of a unified system in the process of the development of true knowledge, the dialectical "movement of truth to itself."

In this research the authors are working on applied philosophizing. They understand applied philosophizing as the type of philosophical thinking, which is based on the concept of philosophy as a system of theoretical knowledge that can be applied to the comprehension of truth in other areas of social cognition and practice. Applied philosophizing is based on the theoretical type of philosophizing and is a consequence of its application.

Applied philosophizing is based on the following provisions:

- Philosophy is the theoretical basis for developing practical recommendations (the "tool") for cognizing an object and / or for changing it.

- The main question of philosophy is the question of "How can knowledge about truth be used in cognition and practice of mastering and / or changing an object?"

Applied philosophizing in one way or another accompanies the theoretical. At the same time, in some philosophical doctrines, it begins to dominate the theoretical philosophizing, giving the latter a secondary role.

Thus, applied philosophizing is evident in the philosophy of Marxism, where theoretical philosophizing (materialistic dialectics) is viewed as a necessary basis for creating a theory of the society development by changing social and economic basis and leading to communism. It ultimately becomes an instrument for the practical transformation of the existing social reality, as the main tool of the proletariat in the struggle against capital.

In another context, there is much applied philosophizing in various doctrines of philosophy and the methodology of science, which view philosophy as the basis for solving the problem of demarcation of scientific knowledge, determining the criteria of scientific character, revealing the logic of the development of science in the variety of theories and types of scientific rationality (positivism, neopositivism, postpositivism, etc.).

Another expression of applied philosophizing is modern teaching, which treats philosophy as a methodology for the cultural analysis of social reality, such as poststructuralism, postmodernism, hermeneutics.

\section{Conclusion}

In the didactic plan, when students study the course "Philosophy," they distinguish three types of philosophizing. This makes possible for them to formulate clearer and more correct ideas about the specifics of philosophical doctrines, schools, and trends. Particularly, the study of a philosophical doctrine should begin with a presentation of the meaning and purpose of philosophy in the understanding of the author of this doctrine in the context of the selected types of philosophizing (Campbell, 2018).

Such a presentation will avoid incorrect comparisons of various philosophical teachings when they are placed in a common area of analysis. So, for example, the comparison of the teachings of Plato and Aristotle cannot be conducted in a 
methodically correct manner without taking into account the different types of philosophizing - practical (in Plato) and theoretical (in Aristotle), which, among other things, is expressed in the various construction of philosophical texts - dialogues by Plato and monologues by Aristotle.

\section{Acknowledgement}

This problem was repeatedly discussed at the methodological sessions of the department, and it was also presented at the international conference "World outlook bases of culture of modern Russia" (May, 2017) in the form of a report. The problem of classification of philosophical doctrines is controversial and ambiguous. However, there are several attempts to justify this problem in the works of modern researchers (Akhmetzyanova et al., 2017).

\section{Bibliographic references}

AKHMETZYANOVA, M.P. - ZHILINA, V.A. - TEPLYKH, M.S. - CHERNOVA, E.G. - NAZARICHEVA, A.I. - SLOBOZHANKINA, L.R. 2017. Cognitive faith as an attributive phenomenon of cognition. In: Man in India, vol. 97, n. 14. pp. 329-339. ISSN: 00251569.

CAMPBELL, L. 2018. An epistemology for practical knowledge. In: Canadian Journal of Philosophy, vol. 48, n. 2, pp. 159-177. ISSN: 00455091.

FOUCAULT, M. 2007. Hermeneutics of the subject. Trans. with fr. St.Petersburg: Science. ISBN: 978-5-02-026922-4

HANSEN, Ch. 2010. Chinese Confucianism and Daoism. In: A Companion to Philosophy of Religion, vol 2, pp. 23-33. DOI: 10.1002/9781444320152.ch3.

HEGEL, G.V. 1993. Lectures on the history of philosophy. St.Petersburg: Science.

KALASHYAN, A.L. 2011. Justification of Philosophy, or Philosophical Truth and Pseudo-Philosophical Lie. In: Voprosy Filosofii, vol. 5, pp. 99-107. ISSN: 00428744. LAERTIUS, D. 2009. On the life, teachings and sayings of the famous philosophers. Moscow: Publishing house: Terra - Book club. ISBN: 978-5-275-01956-8.

MARX, K. - ENGELS, F. 1961. Collected Works. V.21. Moscow: State publishing of political literature.

RANGANATHAN, B. 2018. Description, prescription, and value in the study of religion. In: Religions, vol. 9, n. 1, pp. 10-18. ISSN: 20771444.

RODRIGUEZ, M.G. 2018. The discourse on the end: History, art and philosophy. In: Daimon, vol. 73, pp. 151-165. ISSN: 15788423.

Words: 4014

Characters: 26557 (14,75 standard pages)

Prof. Vera A. Zhilina, Dr. of Philosophy

Economics and Management Institute

Nosov Magnitogorsk State Technical University

38 Lenin Av.

455000 Magnitogorsk

Russia

vera-zhilina@yandex.ru

Assoc. Prof. Leysan R. Slobozhankina, PhD of Education

Institute for the Humanities

Nosov Magnitogorsk State Technical University

38 Lenin Av.

455000 Magnitogorsk

Russia

XLinguae, Volume 11, Issue 2, April 2018, ISSN 1337-8384, eISSN 2453-711X 
Leysanka@gmail.ru

Assoc. Prof. Marina S. Teplykh, PhD of Philosophy

Economics and Management Institute

Nosov Magnitogorsk State Technical University

38 Lenin Av.

455000 Magnitogorsk

Russia

dateplih@mail.ru

Assoc. Prof. Marina P. Akhmetzyanova, PhD of Philosophy

Economics and Management Institute

Nosov Magnitogorsk State Technical University

38 Lenin Av.

455000 Magnitogorsk

Russia

marinka.mgn@mail.ru

Assoc. Prof. Alevtina I. Nazaricheva, PhD of Philosophy

Economics and management Institute

Nosov Magnitogorsk State Technical University

38 Lenin Av.

455000 Magnitogorsk

Russia

alevtina.n76@mail.ru 